\title{
A new genus of the tegotheriid docodonts (Docodonta, Tegotheriidae) from the Early Cretaceous of West Siberia
}

\author{
Evgeny N. Maschenko, Alexey V. Lopatin \& Alexey V. Voronkevich
}

\begin{abstract}
Sibirotherium rossicus gen. et sp. nov. from the Early Cretaceous Ilek Svita in West Siberia (Shestakovo locality) is described based on lower jaw fragments. The lower molars exhibit the typical docodont pattern with the main cusp $a$ connected by transverse crests to the lingual cusps $c$ and $g$. By absence of crests $b-g$ and $c-d$, and presence of crests $b-e$ and $e-g$, as well as by the development of an enlarged anterior basin, Sibirotherium gen. nov. is similar to Tegotherium from the Late Jurassic of Mongolia. These two genera are united in the endemic Asian family Tegotheriidae. The new genus is plesiomorphic in retaining well developed crest $d-f$, and it is more derived than Tegotherium in partial reduction of the crest $e-g$. The morphological diversity of the tegotheriids suggests a significant differentiation of the Late Jurassic — Early Cretaceous docodonts in Asia.
\end{abstract}

KEY WORDS: Sibirotherium rossicus gen. et sp. nov., Tegotheriidae, Docodonta, Early Cretaceous, West Siberia.

Evgeny N. Maschenko [evmash@paleo.ru], Paleontological Institute, Russian Academy of Sciences, ul. Profsoyuznaya 123, Moscow 117647, Russia; Alexey V. Lopatin [alopat@paleo.ru], Paleontological Institute, Russian Academy of Sciences, ul. Profsoyuznaya 123, Moscow 117647, Russia; AlexeyV.Voronkevich [voron@ggf.tsu.ru], Geological-Geographical Faculty, Tomsk State University, pr. Lenina 39, Tomsk 634050, Russia.

\section{Новый род теготериидных докодонтов (Docodonta, Tegotheriidae) из раннего мела Западной Сибири}

\author{
Е.Н. Мащенко, А.В. Лопатин, А.В. Воронкевич
}

\begin{abstract}
РЕЗЮМЕ. На основании фрагментов нижних челюстей из нижнемеловой илекской свиты местонахождения Шестаково в Западной Сибири описан Sibirotherium rossicus gen. et sp. nov. Его нижние коренные зубы имеют типичный для докодонтов тип строения: главный бугор $a$ поперечными гребнями соединен с лингвальными буграми $c$ и $g$. По отсутствию гребней $b-g$ и $c-d$, наличию гребней $b-e$ и $e-g$ и увеличенного переднего бассейна Sibirotherium gen. nov. сходен с Tegotherium из верхней юры Монголии. Эти два рода формируют особое семейство азиатских докодонтов Tegotheriidae. Плезиоморфным признаком нового рода является наличие хорошо развитого гребня $d-f$, а продвинутой по отношению кTegotherium чертой - частичная редукция гребня $e-g$. Известное в настоящее время морфологическое разнообразие теготериид может свидетельствовать о значительной таксономической радиации позднеюрских - раннемеловых докодонтов в Азии.
\end{abstract}

КЛЮЧЕВЫЕ СЛОВА: Sibirotherium rossicus gen. et sp. nov., Tegotheriidae, Docodonta, ранний мел, Западная Сибирь.

\section{Introduction}

The Early Cretaceous vertebrate locality near Shestakovo is known since 1953, when two partial skeletons of the ceratopsian dinosaur Psittacosaurus were found. The Shestakovo sites, situated in the vicinity of the Shestakovo village in the south-east of the West Siberian plain (the Kiya River Basin, Kemerovo Region, Chebula District), are among the most prominent Mesozoic vertebrate localities in Russia. The Lower Cretaceous fossil-bearing deposits of the Ilek Svita were dated as Neocomian based on invertebrates (Osyko, 1958) or Aptian - Albian based on presence of Psittacosaurus (Rozhdestvensky, 1960). Dating of the Shestakovo assemblage is still disputed: different authors estimate its age from the Berriasian-Valanginian to Aptian-Albian (Alifanov et al., 1999; Leshchinskiy et al., 2000, 2001).

First data on Shestakovo Mesozoic mammals were obtained in 1995. Intensive excavations and screenwashing at Shestakovo, carried out since 1995 by a Tomsk University team, with participation of specialists from the Paleontological Institute of the Russian Academy of Sciences, Moscow, and the Zoological Institute of the Russian Academy of Sciences, Saint Petersburg, revealed a diverse vertebrate fauna. Most paleontological finds were discovered in mellow meagre chalky crossbedded coarse-grain sands and sandstones. These deposits possibly represent remains of river-spits in lower or middle reaches. Representatives of about 20 genera and 26 species of vertebrates have been recov- 


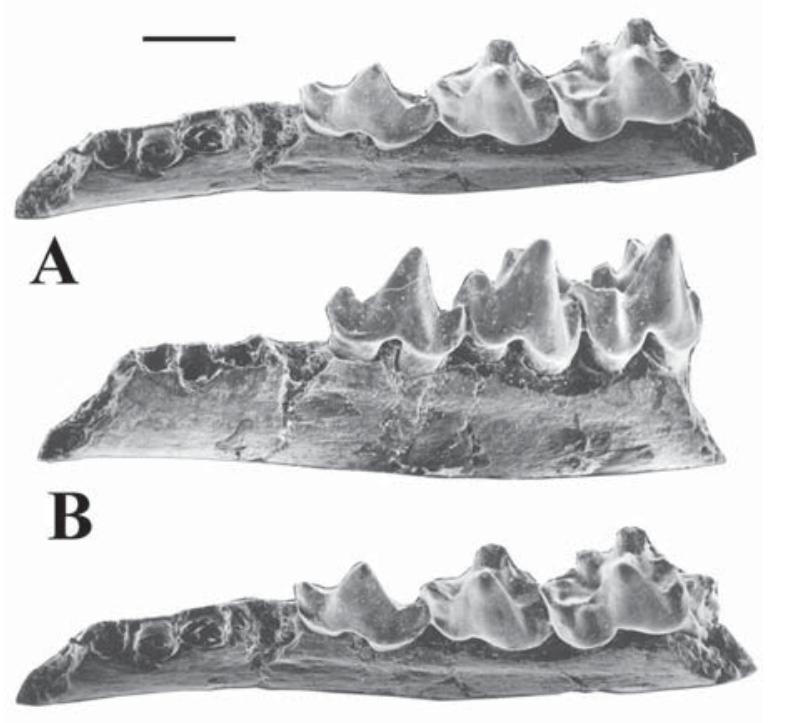

Figure 1.Sibirotherium rossicus gen. et sp. nov., PM TSU 16/ 5-22, holotype, left dentary fragment with dp3(?), dp4(?), and m1. Shestakovo 1, Kemerovo Region, Russia; Ilek Svita, Lower Cretaceous.

A - occlusal and slightly lingual view (stereo pair); B - buccal view. SEM micrographs. Scale bar $1 \mathrm{~mm}$.

ered and identified from Shestakovo: palaeonisciform and sinamiid fishes, amphibians, a "macrobaenid" turtle, lizards, protosuchian and shartegosuchid crocodiles, dinosaurs, pterosaurs, birds, the tritylodontid synapsid Xenocretosuchus sibiricus, the amphilestids Gobiconodon borissiaki, G. hoburensis, Gobiconodon sp. nov. and Amphilestinae indet., the docodont Sibirotherium rossicus gen. et sp. nov., and the peramurid "eupantothere" Kiyatherium cardiodens (Maschenko \& Lopatin, 1998; Tatarinov \& Maschenko, 1999; Efimov \& Leshchinskiy, 2000; Leshchinskiy et al., 2000, 2001; Averianov et al., 2002; Maschenko et al., 2002).

The new docodont is described below. The specimens were found by L.G. Shikhovtseva, E.N. Maschenko, and A.V. Voronkevich in 2000 at the Shestakovo 1 site (Maschenko et al., 2000, 2001). This site is situated on the right bluff of the Kiya River, $1.5 \mathrm{~km}$ downstream

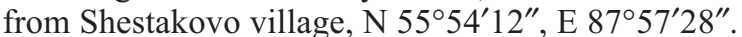

The dental nomenclature and terminology of the Docodonta follows Butler (1997). The lettering of the cusps is coordinated with the descriptive cusp terms used by Kermack et al. (1987) and Sigogneau-Russell (2001): cusp $a$ - main cusp, cusp $b-$ mesiobuccal cusp, cusp $c-$ distolingual cusp, cusp $g$ - mesiolingual cusp, cusp $e-$ lingual anterior cuspule, cuspee - additional anterolingual cingular cuspule, cusp $d$ - buccal posterior cusp, cusp $f$ - lingual posterior cuspule. The ridges between these cusps, respectively, are crests $a-b, a-g, a-c, a-d, b-g, b-e, e-g, c-d, d-f$, and $f-c$. The docodont wear facet terminology is after Jenkins (1969).

The material is housed in the collection of the Paleontological Museum of the Tomsk State University (PM TSU) in Tomsk, Russia.

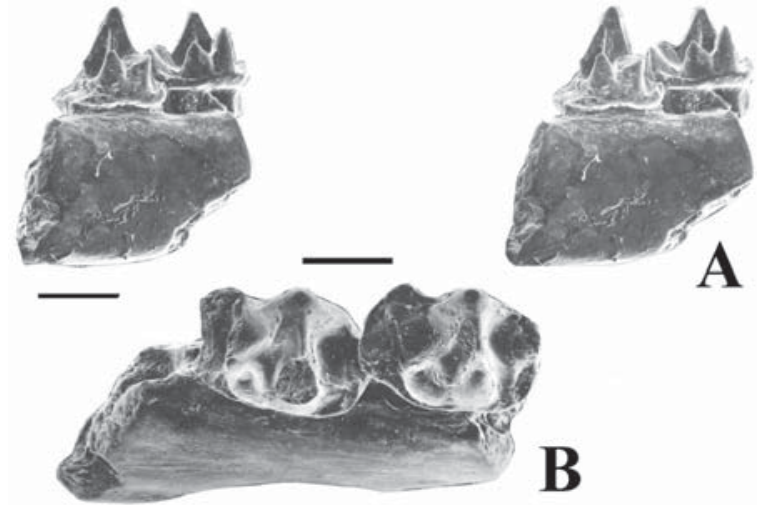

Figure 2.Sibirotherium rossicus gen. et sp. nov., PM TSU 16/ 5-14, right dentary fragment with $\mathrm{m} 2-\mathrm{m} 3($ ?). Shestakovo 1, Kemerovo Region, Russia; Ilek Svita, Lower Cretaceous. A - lingual view (stereo pair); B - occlusal and slightly lingual view. SEM micrographs. Scale bar $1 \mathrm{~mm}$.

\section{Systematic paleontology}

Class Mammalia Linnaeus, 1758

Order Docodonta Kretzoi, 1946

Family Tegotheriidae Tatarinov, 1994

Tegotheriidae: Tatarinov, 1994: 104.

Type genus. Tegotherium Tatarinov, 1994, Late Jurassic of Mongolia.

Included genus. Sibirotherium gen. nov., Early Cretaceous of West Siberia.

Diagnosis. Docodonts with the following combination of primitive (-) and derived $(+)$ characters of the lower molariform teeth: 1) anterior basin ("pseudotalonid") enlarged (+); 2 ) cusp $g$ enlarged $(+) ; 3$ ) cuspule $e$ well developed $(-)$; 4) crest $b-e$ well developed $(-) ; 5)$ crest $b-g$ absent $(+) ; 6)$ crest $e-g$ present $(+) ; 7)$ crest $c-d$ absent $(+) ; 8)$ crest $f-c$ present $(+)$; 9) additional cingular cuspule ee present $(+)$.

Differential diagnosis. Tegotheriidae differs from Docodontidae Simpson, 1929 by characters 3-6, 8, and 9. Also, the tegotheriids differ from all known docodontids, with the exception of Simpsonodon Kermack et al., 1987, by characters 1, 2, and 7. Simpsonodon is convergently similar to Tegotheriidae in having enlarged anterior basin, large cusp $g$, and absence of the distal crests. The tegotheriids differ from a new docodont from the Middle Jurassic of Kyrgyzstan (Martin \& Averianov, in press) by characters 1, 2, 5 and 7.

\section{Genus Sibirotherium gen. nov.}

Type species. S. rossicus sp. nov., Early Cretaceous of West Siberia.

Diagnosis. Differs from Tegotherium Tatarinov, 1994, the only other member of Tegotheriidae, by the following combination of primitive $(-)$ and derived $(+)$ characters of the lower molariform teeth: 1$)$ crest $b-e$ relatively short $(+) ; 2)$ crest $e-g$ interrupted or reduced, not reached the cusp $g(+)$; 3 ) crest $d-f$ well developed ( - . The ultimate lower deciduous tooth is partially molariform, but the anterior basin is not 
enlarged and cusps $e$ and $g$ are absent. The lower postcanine dental formula is p1-4? m1-6?.

Etymology. The generic name is after Siberia and $\vartheta \eta \rho 1-$ ov, beast (Greek).

\section{Sibirotherium rossicus sp. nov.}

Figs. 1-4.

Holotype. PM TSU 16/5-22, a left dentary fragment with $\mathrm{dp} 3, \mathrm{dp} 4$, and $\mathrm{m} 1$.

Referred material. PM TSU $16 / 5-14$, a right dentary fragment with $\mathrm{m} 2-\mathrm{m} 3(?)$; PM TSU $16 / 5-2$, a left dentary fragment with $\mathrm{m} 4-\mathrm{m} 5(?)$ and fragments of $\mathrm{m} 3(?)$ and $\mathrm{m} 6(?)$.

Type locality. Shestakovo 1, Chebula District, Kemerovo Region, Russia.

Stratigraphic level. Ilek Svita, Lower Cretaceous.

Diagnosis. As for the genus.

Etymology. The species name is after Russia, the country of provenance.

Description. The holotype is the fragment of a left dentary, with three slightly worn teeth: the penultimate and ultimate deciduous premolars (presumably, dp3 and dp4), and first molar $(\mathrm{m} 1)$. Anterior to the penultimate deciduous premolar, there are four alveoli for two more anterior deciduous(?) premolars. Judging by the alveoli, the size of the deciduous premolars is dp1 $<\mathrm{dp} 2<\mathrm{dp} 3>\mathrm{dp} 4$. Mental foramina and symphysis region are not preserved in the dentary. The mandible is shallow; the depth of the dentary is approximately equal to height of the molar crown. The deciduous premolars and molar possess two well separated roots of approximately equal size.

The penultimate deciduous premolar has a strong lingual cingulid, and a very small and short anterior buccal cingulid at the level of the mesial cusp. There are three cusps placed in linear arrangement. The highest main cusp is situated in the center of the crown. Mesial and distal accessory cusps are considerably smaller than the main cusp. Longitudinal crests run from the tip of the main cusp to both the mesial and distal cusps. All cusp are slightly worn apically.

The dp4 structure is intermediate between that of $\mathrm{dp} 3$ and $\mathrm{m} 1$. Dominant main cusp $a$ is connected by sharp crests with the mesial cusp $b$ and distal cusp $d$. There are a large cusp $c$ and prominent transverse crest $a-c$. The anterior transverse crest is very weak, and is connected with the base of cusp $c$. Cuspg is absent. The anterior basin is small and shallow. Cusp $e$ is absent. The cuspules $d$ and $f$ are very small, connected by a distinct long crest $d-f$. Crest $f-c$ is absent. Lingual cingulid is prominent, but it is interrupted at the level of cusp $c$. The reduced buccal cingulid is weakly developed at the level of cusp $b$ only. Wear facets are developed on the tips of cusps $a$ (facet $1 a$ ), $b$ (facet $4 a$ ), and along the crest $d-f$ (facets $11 c$ and 11d). The apex of cusp $c$ is broken off.

The crown of $\mathrm{m} 1$ is rectangular in outline. Large conical cusp $a$ has a slightly concave lingual surface and a rounded buccal side. There are four crests running from the tip of cusp $a$ : two longitudinal crests $(a-b$ and $a-d)$, and two transverse crests $(a-g$ and $a-c)$. Crest $a-g$ is directed mesiolingually, and crest $a-c$ extends distolingually. The angle between transverse crests is about $40^{\circ}$. Cusp $a$ bears a wear facet $l a$ at the tip which extends downwards along crest $a-c$ (facet 3 ). Crests $a-b$ and $a-d$ are sharp. The crest $a-g$ is somewhat rounded, and bears no wear facet.

Cusp $c$ is the second highest cusp on $\mathrm{m} 1$. It is considerably lower than cusp $a$ (apically broken off). Cuspg is significantly smaller and lower than cusp $c$. A rather strong apical wear facet $(7 a)$ is developed on this cusp. Bases of cusps $c$ and $g$ are not connected, with a distinct space between them. Cusp $b$ is

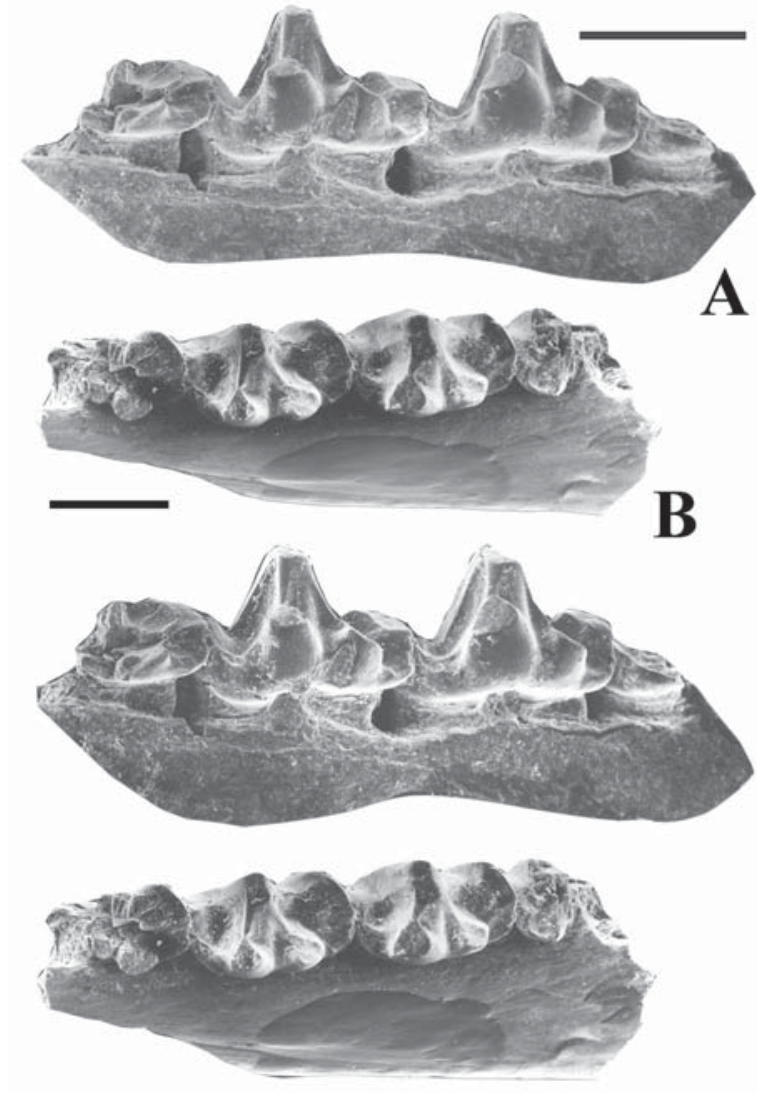

Figure 3. Sibirotherium rossicus gen. et sp. nov., PM TSU 16/5-2, left dentary fragment with $\mathrm{m} 4-\mathrm{m} 5(?)$ and fragments of m3(?) and m6(?). Shestakovo 1, Kemerovo Region, Russia; Ilek Svita, Lower Cretaceous.

A - lingual and slightly occlusal view. Scale bar $0.3 \mathrm{~mm}$; B occlusal and slightly lingual view. Scale bar $1 \mathrm{~mm}$. SEM micrographs (stereo pairs)

considerably smaller than cusp $c$, but somewhat larger and higher than cusp $g$. Cusps $b$ and $a$ are placed along the buccal border of the crown. There is a distinct side wear facet $(1 c)$ on the anterior and buccal slopes of cusp $b$, anteriorly from the buccal fold between cusps $b$ and $a$. Cusp $b$ is connected with crests $a-b$ and $b-e$. Crest $b-e$ is short and high. Cusp $e$ is approximately equal in height to $\operatorname{cusp} b$, but is much less stout. Lingually, there is an additional cingular cusp ee. Well developed creste- $g$ does not reach cusp $g$. Between the square formed by crests $a-b, b-e, e-g$, and $a-g$, there is a rather deep anterior basin with slight crenulations on the lingual slope of cusp $b$.

A small cusp $d$ forms the buccal end of the prominent crest $d-f$. At the lingual end of this crest there is a small cusp $f$, which bears a distinct wear facet. Between crests $a-c$ and $d-$ $f$ there is a rather deep circular posterior basin. It is bounded by crest $a-d$ buccally, and by the very thin and short crest $f-$ $c$ lingually. Crest $f-c$ is connected to the posterior base of cusp $c$, but it does not ascend on the wall of this cusp. There are no prominent cingulids at the base of the crown, with the exception of the anterolingual and posterolingual corners of the tooth. The posterior end of the crown is somewhat oblique.

The second specimen, PM TSU 16/5-14, is a fragment of a right dentary with two unworn molars, probably $\mathrm{m} 2$ (ante- 

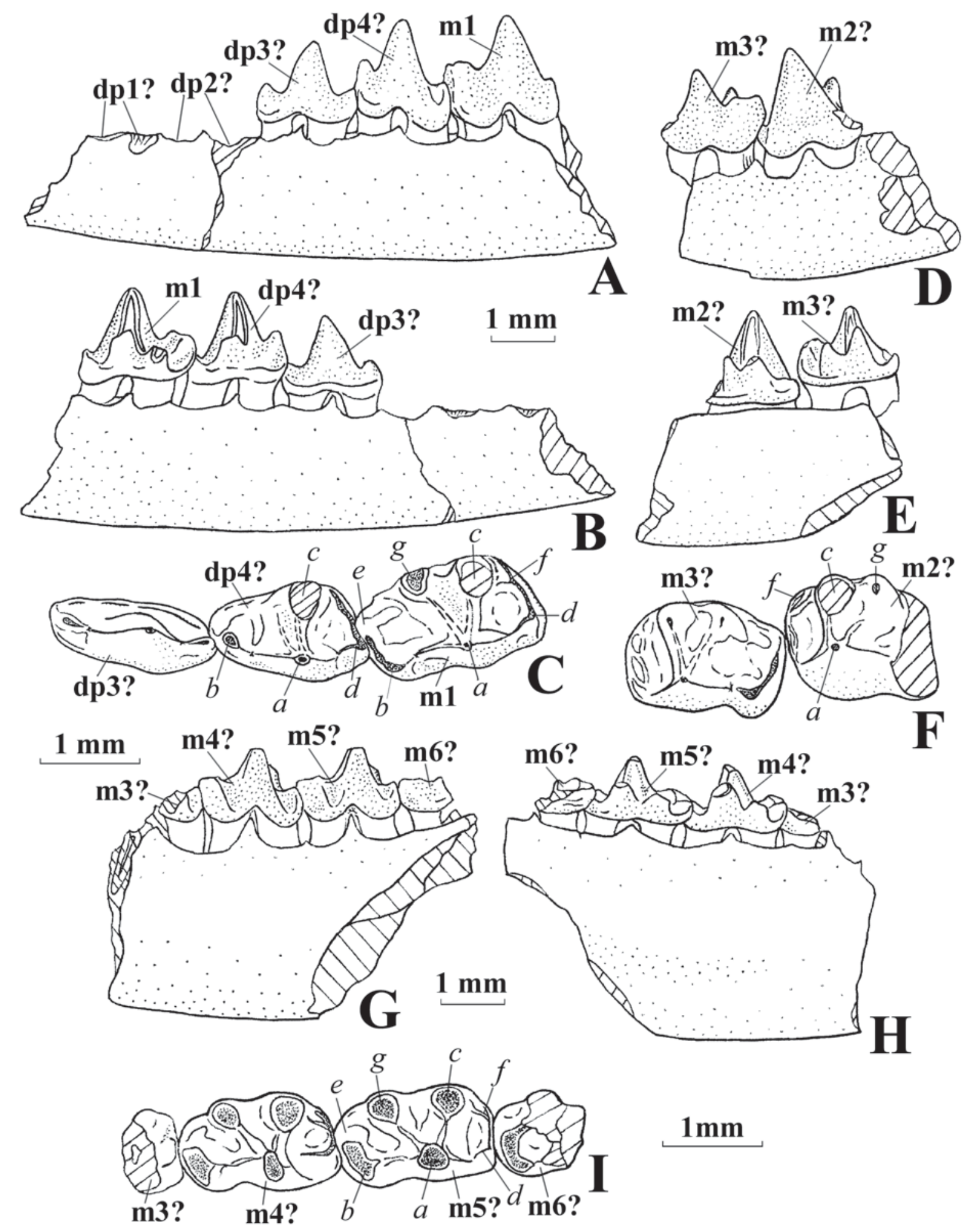

Figure 4. Sibirotherium rossicus gen. et sp. nov. Shestakovo 1, Kemerovo Region, Russia; Ilek Svita, Lower Cretaceous. A-C - PM TSU 16/5-22, holotype, left dentary fragment with dp3(?), dp4(?), and $\mathrm{m} 1$ (A - buccal, B — lingual views, C — occlusal view of teeth); D-F - PM TSU 16/5-14, right dentary fragment with $\mathrm{m} 2-\mathrm{m} 3($ ?) (D - buccal, E - lingual views, F — occlusal view of teeth); G-I - PM TSU 16/5-2, left dentary fragment with m4-m5(?) and fragments of m3(?) and m6(?) (G—buccal, H — lingual views, I — occlusal view of teeth). Scale bar $1 \mathrm{~mm}$. 
rior lobe is broken off) and $\mathrm{m} 3$. The depth of the dentary fragment and size of the teeth suggest that the preserved molars belong to the anterior half of the molar row. However, the structure of the anterior preserved tooth differs from that in $\mathrm{m} 1$. Thus, this tooth may be a $\mathrm{m} 2$, and the following is a $\mathrm{m} 3$. The posterior end of both teeth is straight, not oblique as in $\mathrm{m} 1$. Cusp $a$ is more robust in $\mathrm{m} 2$ than in $\mathrm{m} 3$. Cusps $c$ and $g$ are connected at their bases, but are separated by a wide and deep notch. The posterior basin is wider, and crest $f-c$ is more prominent than in $\mathrm{m} 1$, highly ascending on the posterior wall of cusp $c$. The anterolingual cingulid is present at the level of cusps $b$ and $g$. The crown of $\mathrm{m} 3$ is shorter than that of $\mathrm{m} 1$ or $\mathrm{m} 2$, with a considerably lower main cusp. Principally, the $\mathrm{m} 3$ structure does not differ from that of $\mathrm{m} 1$ and $\mathrm{m} 2$, but crest $a$ $g$ does not reach the base of cusp $g$, crest $e-g$ is interrupted in the middle, and crest $f-c$ is absent. Cusps $c$ and $g$ are connected at their bases. The wear facet on $\operatorname{cusp} f$ is relatively large. There are distinct crenulations between crests $a-c$ and $d-f$. The lingual cingulid is well developed, almost complete, but interrupted at the level of cusp $c$. Cusps $a, c$, and $g$ have strong apical wear facets, $1 a, 9 a$, and $7 a$, respectively. Distinct short wear facets 3 and $9 b$ are present along crest $a-c$. They are separated by a deep notch.

The third specimen, PM TSU $15 / 5-2$, is a fragment of the posterior part of a left dentary, containing two strongly worn complete molars, and two molar fragments anteriorly and posteriorly from them. The smallest last molar in this fragment is interpreted as the ultimate molar in the tooth series. Because the molar count of Tegotheriidae is unknown, and other docodont molars differ considerably from that of the specimens described above, we cannot specify the homology of these teeth precisely. However, the shapes of the main cusps of the complete molars suggest that these teeth come from a position posterior to $\mathrm{m} 2$. Moreover, the shape of the posterior basin of the most anterior preserved fragmented tooth is similar to that of $\mathrm{m} 3$ on specimen PM TSU 15/5-14. Thus, tentatively, we interpret the molars described below as fragmented $\mathrm{m} 3$, complete $\mathrm{m} 4$ and $\mathrm{m} 5$, and fragmented $\mathrm{m} 6$.

The preserved part of the mandible is deep, the dentary is approximately twice as deep as the molar crowns. The Meckel's groove is shallow, but relatively wide. It is well developed under $\mathrm{m} 6$ and $\mathrm{m} 5$, and hardly visible under $\mathrm{m} 4$ (Figs. 3B, 4H). The groove is located at the level of one third of the dentary depth.

The preserved fragment of $\mathrm{m} 3$ exposes a small posterior basin, cusp $d$, minute cusp $f$, and short crest $d-f$, and a small cingulid in the posterolingual corner of crown.

The crowns of $\mathrm{m} 4$ and $\mathrm{m} 5$ are equal in length and height. Cusp $a$ is not so massive as in $\mathrm{m} 1$ or $\mathrm{m} 2$, but it is similar to that in $\mathrm{m} 3$. The angle between transverse crests $a-g$ and $a-c$ is about $60^{\circ}$. Strong wear facets descend along crests $a-b$ and $a-$ $d$. There is a space between cusps $g$ and $c$. Cusp $c$ is half as high as cusp $a$, and it bears a strong wear facet $9 a+9 b$. Cuspg is two times smaller and lower than cusp $c$. A strong apical wear facet (7a) is developed on this cusp, too. There is a deep buccal fold between cusps $b$ and $a$. Cusps $b$ and $e$ are twinned. They have one undivided wear facet. Crest $e-g$ is reduced, very weak and interrupted in the middle. The drop-shaped anterior basin is relatively small and shallow. The anterolingual cingulid is well developed. Cusps $d$ and $f$ are distinct, and crest $d-f$ is short. Cusp $f$ is connected to the posterior base of cusp $c$ by a short crest $f-c$. The circular posterior basin is small. A lingual cingulid is not present.

Structure of $\mathrm{m} 5$ does not differs from that of $\mathrm{m} 4$, except in the lower size differentiation between cusps $c$ and $g$, and larger posterior basin. Crest $e-g$ is more reduced, cusps $e$ and $g$ are well separated by a wide lingual fold. Cingular cuspule $e e$ is well developed. Cusp $d$ is relatively large. Crest $f-c$ highly ascends on the posterior wall of cusp $c$. Judging by the fragment of the anterior lobe of 6 , this tooth was much smaller than $\mathrm{m} 4$ or $\mathrm{m} 5$, and possibly had a complete crest $e-g$.

Measurements (all in mm). Holotype: dp3: length 1.60, width 0.75 , height $1.35 ;$ dp 4 : length 1.50 , width 1.10 , height $1.75 ; \mathrm{m} 1$ : length 1.90 ; width 1.20 , height 1.75 ; dentary depth below dp4 2.0, below $\mathrm{m} 12.3$.

Specimen PM TSU 16/5-14: m2: width 1.30, height 1.70; $\mathrm{m} 3$ : length 1.65 ; width 1.10 , height 1.30 ; dentary depth below $\mathrm{m} 2$ 2.0.

Specimen PM TSU 16/5-2: m4: length 1.60, width 1.10, height 1.25 ; m5: length 1.60 ; width 1.05 , height 1.20 ; dentary depth below m4 3.00.

Remarks. The structure of the ultimate deciduous premolar of Sibirotherium rossicus gen. et sp. nov. is similar to that of Docodon ["Peraiocynodon"] (Butler, 1939) and Haldanodon (Krusat, 1980: figs. 23, 24). However, in comparison to Docodon, the penultimate deciduous premolar of Sibirotherium gen. nov. exhibits the more simplified pattern, without cusp $c$ and crest $a-c$. The two anterior deciduous premolars are double-rooted, as dp1 and dp2 of Docodon.

\section{Discussion}

At present the order Docodonta includes few genera: the Middle Jurassic European Borealestes Waldman et Savage, 1972, Simpsonodon Kermack et al., 1987, and Cyrtlatherium Freeman, 1979 (possible synonym of the latter); Docodon Marsh, 1881 from the Late Jurassic of North America and Early Cretaceous of Europe, the Late Jurassic European Haldanodon Kühne et Krusat, 1972, a new Middle Jurassic taxon from Kyrgyzstan, and the Late Jurassic Tegotherium Tatarinov, 1994 from Mongolia (Simpson, 1929; Kretzoi, 1946; Kühne \& Krusat, 1972; Waldman \& Savage, 1972; Kron, 1979; Krusat, 1980; Kermack et al., 1987; Lillegraven \& Krusat, 1991; Tatarinov, 1994; Martin \& Nowotny, 2000; Martin \& Averianov, in press). The newly described genus, the Early Cretaceous Asian Sibirotherium gen. nov., increases our knowledge on the temporal and geographic distribution of Docodonta, being the first docodont from Siberia and the youngest record for the whole group.

Martin \& Averianov (in press) performed a phylogenetic analysis of all known docodont taxa based on lower molar characters. They followed the idea by Butler (1997) that docodonts were derived from a Woutersialike mammal, having a main cusp $a$, a lingually displaced $\operatorname{cusp} c, \operatorname{cusp} b$ in a more buccal position, well developed cusps $e, g$, and $d$, and three main crests connecting some of the cusps: $a-c, a-b$, and $b-e$. They reconstructed the next hypothetical stage in the development of docodont lower molars, with additional four ridges (crests $d-f, c-$ $d, a-g$, and $b-g$ ) and one cusp (f). Crest $a-g$ is present in all known docodonts, but other crests have been secondarily lost in some taxa. Martin \& Averianov (in press) suggest that after this stage docodonts split into two main branches: Euroamerican docodonts and Asian docodonts. The discovery of Sibirotherium gen. nov. confirms Martin's \& Averianov's hypothesis. 
The Asian branch of the docodonts includes the family Tegotheriidae and one genus outside this family (Martin \& Averianov, in press). Mainly, Tegotheriidae are characterized by the following characters in the lower molariform teeth: an enlarged anterior basin ("pseudotalonid"), a large cusp $g$, well developed cuspule $e$ and crests $b-e, e-g, f-c$, and absence of crests $b-g$ and $c-d$.

Tegotherium is known by one lower molar from the Late Jurassic Shar-Teg locality in Mongolia (Tatarinov, 1994; Kielan-Jaworowska et al., 2000; Martin \& Averianov, in press). Sibirotherium gen. nov. is similar to Tegotherium by absence of crests $b-g$ and $c-d$, and presence of crests $b-e$ and $e-g$, as well as by the development of an enlarged anterior basin. Sibirotheri$u m$ gen. nov. is plesiomorphic in retaining well developed crest $d-f$, and it is more derived than Tegotherium in partial reduction of the crest $e-g$. Sibirotherium rossicus gen. et sp. nov. is much larger than Tegotherium gubini Tatarinov, 1994. The molars of S. rossicus gen. et sp. nov. are 1.6 to 1.9 time longer, than the tooth of $T$. gubini. Representing the most complete and wellpreserved tooth row among Asian docodonts, S. rossicus gen. et sp. nov. considerably increases our knowledge on the morphology of this group.

Thus, Tegotherium and Sibirotherium gen. nov. form the separate Asian docodontan family Tegotheriidae. Newly known morphological diversity of the Asian docodonts suggests a significant differentiation of this branch of the order.

ACKNOWLEDGMENTS. We thank Dr. Alexander O. Averianov (Zoological Institute RAS, St.-Petersburg) for very useful critical comments, Dr. Thomas Martin (Freie Universität, Berlin) for reviewing of the paper and useful comments. The work was supported by the Russian Fund of Basic Research grant 01-04-49548.

\section{References}

Alifanov V.R., Efimov M.B., Novikov I.V. \& Morales M. 1999. [A new psittacosaur complex of tetrapods from the Lower Cretaceous Shestakovo locality (southern Siberia)] // Doklady Akademii Nauk. T.369. No.4. P.491-493 [in Russian].

Averianov A.O., Voronkevich A.V., Maschenko E.N., Leshchinskiy S.V. \& Fayngertz A.V. 2002. A sauropod foot from the Early Cretaceous of Western Siberia, Russia // Acta Paleontologica Polonica. Vol.47. No.1. P.117-124.

Butler P.M. 1939. The teeth of the Jurassic mammals // Proceedings of the Zoological Society of London, Series B. Vol.109. P.329-356.

Butler P.M. 1997. An alternative hypothesis on the origin of docodont molar teeth // Journal of Vertebrate Paleontology. Vol.17. No.2. P.435-439.

Efimov M.B. \& Leshchinskiy S.V. 2000. [First record of the fossil crocodile skull in Siberia] // A.V. Komarov (ed.) [Materials of the Regional Conference of the Geologists of Siberia, Far East and North East of Russia]. T.2. Tomsk: GalaPress. P.381-363 [in Russian].
Jenkins F.A. 1969. Occlusion in Docodon (Mammalia, Docodonta) // Postilla. No.139. P.1-24.

Kermack K.A., Lee A.J., Lees P.M. \& Mussett F. 1987. A new docodont from the Forest Marble // Zoological Journal of the Linnean Society. Vol.89. P.1-39.

Kielan-Jaworowska Z., Novacek M.J., Trofimov B.A. \& Dashzeveg D. 2000. Mammals from the Mesozoic of Mongolia // M.J. Benton, M.S. Shishkin, D.M. Unwin \& E.N. Kurochkin (eds.). The Age of Dinosaurs in Russia and Mongolia. Cambridge: Cambridge University Press. P.571-624.

Kretzoi M. 1946. On Docodonta, a new order of Jurassic Mammalia // Annales Historico-Naturales Musei Nationalis Hungarici. Vol.39. No.1-10. P.108-111.

Kron D.G. 1979. Docodonta // J.A. Lillegraven, Z. KielanJaworowska \& W.A. Clemens (eds.). Mesozoic Mammals: The First Two-Thirds of Mammalian History. Berkeley: University of California Press. P.91-98.

Krusat G. 1980. Contribução para o conhecimento da fauna do Kimeridgiano da Mina de lignito Guimarota (Leiria, Portugal). IV Parte. Haldanodon exspectatus Kühne \& Krusat 1972 (Mammalia, Docodonta) // Memórias dos Serviços Geológicos de Portugal. Vol.27. P.1-79.

Kühne W.S. \& Krusat G. 1972. Legalisierung das taxon Haldanodon (Mammalia, Docodonta) // Neues Jahrbuch für Geologie und Paläntologie, Monatshefte. Hf.5. S.300302.

Leshchinskiy S.V., Fayngertz A.V., Voronkevich A.V., Maschenko E.N. \& Averianov A.O. 2000. [Preliminary results of the investigation of the Shestakovo localities of Early Cretaceous vertebrates] // A.V. Komarov (ed.). [Materials of the Regional Conference of the Geologists of Siberia, Far East and North East of Russia]. T.2. Tomsk: GalaPress. P.363-366 [in Russian].

Leshchinskiy S.V, Voronkevich A.V., Fayngertz A.V., Maschenko E.N., Lopatin A.V. \& Averianov A.O. 2001. Early Cretaceous vertebrate locality Shestakovo, Western Siberia, Russia: a refugium for Jurassic relicts? // Journal of Vertebrate Paleontology. Vol.21. Supplement to No.3. P.73A.

Lillegraven J.A. \& Krusat G. 1991. Cranio-mandibular anatomy of Haldanodon exspectatus (Docodonta; Mammalia) from the Late Jurassic of Portugal and its implications to the evolution of mammalian characters // Contributions to Geology, University of Wyoming. Vol.28. No.2. P.39138.

Martin T. \& Averianov A.O. (in press). A docodont (Mammaliaformes) from the Middle Jurassic of Kyrgyzstan // Journal of Vertebrate Paleontology.

Martin T. \& Nowotny M. 2000. The docodont Haldanodon from the Guimarota mine // T. Martin \& B. Krebs (eds.). Guimarota - a Jurassic Ecosystem. Munchen: Verlag Dr. Friedrich Pfeil. P.91-96.

Maschenko E.N. \& Lopatin A.V. 1998. First record of an Early Cretaceous triconodont mammal in Siberia// Bulletin de l'Institute Royal des Sciences Naturelles de Belgique. T.68. P.233-236.

Maschenko E.N., Lopatin A.V. \& Voronkevich A.V. 2000. [New Early Cretaceous mammals from Shestakovo locality (Kemerovo Region)] // N.V. Kruchinina \& T.L. Modzalevskaya (eds.). [Paleontology in Russia: Results and 
Perspectives. Abstracts of Reports on $46^{\text {th }}$ Session of the Paleontological Society at RAS]. Sankt-Peterburg: Paleontologicheskoe Obshchestvo. P.61-62 [in Russian].

Maschenko E.N., Lopatin A.V. \& Voronkevich A.V. 2001. [Early Cretaceous pseudotribosphenic mammals from Shestakovo-1 locality (southeastern West Siberia)] // V.M. Podobina (ed.). [Evolution of Life on the Earth]. Tomsk: Izdatel'stvo Nauchno-Technicheskoi Literatury. P.451 [in Russian].

Maschenko E.N., Lopatin A.V. \& Voronkevich A.V. 2002. [New Early Cretaceous mammal from West Siberia] // Doklady Akademii Nauk. T.386. No.5. P.715-716 [in Russian].

Osyko T.I. 1958. [West Siberian depression and eastern slope of the Ural mountains] // N.K. Ovechkin (ed.). [Geological Structure of the USSR]. T.1. Moskva: Gosudarstvennoe Nauchno-Technicheskoe Izdatel'stvo po Geologii i Okhrane Nedr. P.460-466 [in Russian].
Rozhdestvensky A.K. 1960. [Early Cretaceous dinosaur locality in Kuzbass] // Paleontologicheskii Zhurnal. No.2. P.165 [in Russian].

Sigogneau-Russell D. 2001. Docodont nature of Cyrtlatherium, an upper Bathonian mammal from England // Acta Palaeontologica Polonica. Vol.46. No.3. P.427-430.

Simpson G.G. 1929. American Mesozoic Mammalia // Memoirs of the Peabody Museum. Vol.3. Pt.1. P.1-235.

Tatarinov L.P. 1994. [On an unusual mammalian tooth from the Mongolian Jurassic] // Paleontologicheskii Zhurnal. No.2. P.97-105 [in Russian].

Tatarinov L.P. \& Maschenko E.N. 1999. [A find of an aberrant tritylodont (Reptilia, Cynodontia) in the Lower Cretaceous of Kemerovo Region] // Paleontologicheskii Zhurnal. No.4. P.85-92 [in Russian].

Waldman M. \& Savage R.J.G. 1972. The first Jurassic mammal from Scotland // Journal of the Geological Society. Vol.128. P.119-125. 